\title{
Antibiotic resistance in the environment
}

\section{G. Joakim Larsson (10) ${ }^{1,2 \bowtie}$ and Carl-Fredrik Flach (i) ${ }^{1,2}$}

Abstract | Antibiotic resistance is a global health challenge, involving the transfer of bacteria and genes between humans, animals and the environment. Although multiple barriers restrict the flow of both bacteria and genes, pathogens recurrently acquire new resistance factors from other species, thereby reducing our ability to prevent and treat bacterial infections. Evolutionary events that lead to the emergence of new resistance factors in pathogens are rare and challenging to predict, but may be associated with vast ramifications. Transmission events of already widespread resistant strains are, on the other hand, common, quantifiable and more predictable, but the consequences of each event are limited. Quantifying the pathways and identifying the drivers of and bottlenecks for environmental evolution and transmission of antibiotic resistance are key components to understand and manage the resistance crisis as a whole. In this Review, we present our current understanding of the roles of the environment, including antibiotic pollution, in resistance evolution, in transmission and as a mere reflection of the regional antibiotic resistance situation in the clinic. We provide a perspective on current evidence, describe risk scenarios, discuss methods for surveillance and the assessment of potential drivers, and finally identify some actions to mitigate risks.

Many bacterial species evolved the ability to tolerate antibiotics long before humans started to mass-produce them to prevent and treat infectious diseases ${ }^{1,2}$. Isolated caves $^{2}$, permafrost cores ${ }^{1}$, and other environments and specimens that have been preserved from anthropogenic bacterial contamination ${ }^{3,4}$ can provide insights into the resistance mechanisms that prevailed during the pre-antibiotic era. An important driver of the ancient and still ongoing evolution of resistance mechanisms is likely to be the never-ending competition for resources among microorganisms, including the natural production of secondary metabolites that are similar to many of the antibiotics used today as pharmaceuticals ${ }^{5-7}$. The relatively recent introduction of antibiotics as clinical agents radically changed the preconditions for the evolution and spread of resistance by providing unprecedented selection pressures, especially on members of the microbiota of humans and domestic animals, but also in environments heavily polluted with antibiotics. This selection pressure has promoted the mobilization and horizontal transfer of a large range of antibiotic resistance genes (ARGs) ${ }^{8}$ to many bacterial species, particularly to those causing disease. The ultimate, well-known consequences of such accumulating evolutionary events are gradually increasing difficulties to prevent and treat bacterial infections. As bacteria and genes often cross environments and species boundaries, it is critical to understand and acknowledge the connections between the human, animal and environmental microbiota (the One Health Concept ${ }^{9,10}$ ) to manage this global health challenge $^{11-23}$. In this Review, we describe our current understanding of the role of the environment in the evolution of resistance and as a route for transmission of resistant bacteria that already circulate in humans. We elaborate on how studies of resistance in the environment could provide a reflection of the regional clinical resistance situation, thereby complementing traditional surveillance. Furthermore, we provide a critical account of the methods used to study antibiotic resistance in the environment, particularly with regard to the assessment of selection pressures. Finally, we identify some principles that could guide strategies to reduce risks, with particular focus on challenges in low- and middle-income countries (BOX 1) and emissions from antibiotic manufacturing.

\section{Resistance evolution in the environment}

Antibiotic resistance can arise both from mutations in the pre-existing genome of a bacterium and from the uptake of foreign DNA. Mutations readily occur and become fixed in the patient or animal treated with the antibiotic. Such a strong selection pressure on pathogens is rarer elsewhere. The process is also independent of the genetic reservoir in other species. 


\section{Box 1 | The antibiotic resistance crisis in low- and middle-income countries}

Many low- and middle-income countries (LMICs) are particularly vulnerable to the antibiotic resistance crisis. This is because of, for example, limited surveillance and diagnostic opportunities, less-controlled use of antibiotics in both humans and animals, overcrowding in hospitals, insufficient hygiene control, often rapidly growing meat and fish production, an overall greater infection burden, and limited access to expensive, second-line or third-line antibiotics ${ }^{167}$. The environmental dimensions can also be more important in these regions, for example, as a consequence of inferior infrastructure for managing human and animal waste streams, leading to greater environmental emissions of both resistant faecal bacteria and residual antibiotics ${ }^{168,169}$. Owing to low production costs, China and India have become the world's largest producers of antibiotics. Insufficient waste management and excessive emissions of antibiotic residues from manufacturing have been reported in those countries, as well as in other regions of the world ${ }^{58,61}$. Management is often more challenging in LMICs than in highincome countries because of more limited resources, other pressing basal needs that need to be addressed, and a weaker governance of and trust in the public sector. Resolving the resistance crisis in LMICs is needed, not only for the LMICs themselves but also because resistant bacteria do not recognize borders. Resource-efficient management should therefore include intensified actions in LMICs. Such initiatives may often overlap with strategies to improve water quality, sanitation and hygiene ${ }^{21}$. Sewage surveillance to assess the clinical resistance situation probably also has its greatest future potential in LMICs being less resource-demanding than traditional clinical surveillance systems. known to often carry such elements or possibly because the conditions (including reoccurring stress) favour frequent gene exchanges ${ }^{37,38}$. The third step is the horizontal transfer of a mobilized resistance gene, either directly to a pathogen or via one or several intermediary bacterial hosts. The fourth step, which may occur at any time in the process, is the physical transfer of the bacterium carrying the ARG to the human or domestic animal microbiota, an ability described by the term 'ecological connectivity' ${ }^{39}$. High metabolic activity and extensive cell-to-cell contact (such as in biofilms) are probably increasing the rate of most steps. All of these steps, including mobilization by, for example, insertion sequences ${ }^{40}$ or integrons ${ }^{41}$, increases in donor cell abundance and thus transfer opportunities, and the rate of horizontal gene transfer (HGT) ${ }^{42,43}$, may be promoted by antibiotics. Importantly, though, most if not all steps also occur in the absence of antibiotics, but at different rates $^{44,45}$. Hence, it is crucial to understand where the bottlenecks are in the evolution towards resistance in pathogens. A critical bottleneck is likely to be the selection of the rare genotypes with acquired resistance that result from mobilization and/or HGT, genotypes that otherwise would disappear ${ }^{46}$. At all stages, compensatory mutations somewhere in the genome of the bacterium carrying the ARG may occur, lowering potential fitness costs, either through reducing niche overlap or by increasing competitive ability ${ }^{47}$. The emergence of new ARGs in the clinic occurs only when all events align in time and space ${ }^{48}$.

In principle, all, some or none of the evolutionary steps could occur in the external environment. Of 22 ARGs with strong evidence for their recent origin down to species level, 21 came from species that at least occasionally are associated with infections in humans and/or domestic animals ${ }^{49}$. This strong over-representation is coherent with the hypothesis that human and/or domestic animals provide the most important environments for resistance evolution under a selection pressure from antibiotics. That said, for the overwhelming majority of ARGs, their recent origin is not known, quite possibly because they originate from environmental species that have not been sequenced yet. This alternative hypothesis speaks in favour of a much greater role of the external environment.

While the introduction of new ARGs to pathogens is worrying, changes in the genetic context around ARGs that affect the level of resistance, co-selection opportunities, or virulence or transmission potential can also add to the resistance challenge. The consequences of evolutionary events leading to the emergence of pathogens with new, successful resistance genotypes through any of these routes differ profoundly from those of transmission events of already widely circulating genotypes (as described later). Even single events can lead to the irreversible ${ }^{50}$ global spread of a new genotype that is it more challenging to treat. Compared with transmission, critical evolutionary events are rare and to some extent unique in nature, which is why they are more difficult to predict. Nonetheless, the benefits from being able to delay or prevent their emergence can be substantial. 


\section{Pollution as a driver}

Although the natural production of antibiotic molecules most likely contributed to the (more ancient) evolution of $A R G s^{5}$, it is not responsible for the rapid evolutionary expansion and spread of resistance factors across strains, species and environments that we have observed since the introduction of antibiotics as therapeutic agents. Antibiotics produced by environmental microorganisms are widespread, but act largely on a microscale, as concentrations characteristically would be expected to drop rapidly around the producing organisms, hence limiting exposure. Man-made antibiotics, on the other hand, act on a macroscale and are typically associated with selection pressures across entire microbial communities.

Antibiotics reach the environment via excretions (urine and faeces) from humans and domestic animals ${ }^{51-53}$, through improper disposal and/or handling of unused drugs $^{54}$, through direct environmental contamination in aquaculture ${ }^{55,56}$ or plant production ${ }^{57}$, and via waste streams from the production of antibiotics ${ }^{58-62}$ (FIG. 2).
Undoubtedly, the most widespread emissions, and quite plausibly the largest proportion of released antibiotics, are the result of use and excretion. At the same time, exposure levels via this route are always limited by, for example, the proportion of the population that is using the antibiotic at a given time, the doses used and metabolism in the human or domestic animal.

With some exceptions, environmental concentrations of antibiotics are low, much lower than the minimal inhibitory concentrations (MICs) and most often lower than concentrations predicted (or shown) to select for resistant strains in the laboratory ${ }^{63,64}$. Although the concentration of antibiotics and the abundance of ARGs often correlate in environmental samples, in many cases this can be explained simply by different levels of pollution with human excreta, which is a source for both, rather than on-site selection of resistant bacteria in the environment by the antibiotic residues ${ }^{65}$. Still, the concentrations suspected to select for resistance (see later) are exceeded in many places, such as in sewage treatment
Chromosomal,
immobile ARG
ARG mobilization within the genome by, for example, ISs or integrons
Relocation to an element that can move autonomously between cells
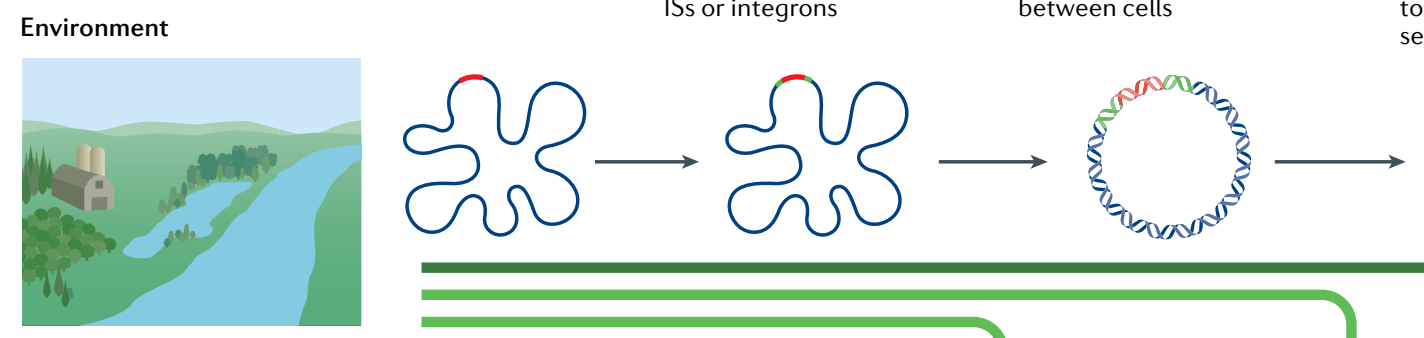

Horizontal transfer of such a mobile element, either directly to a pathogen or via one or several intermediary hosts
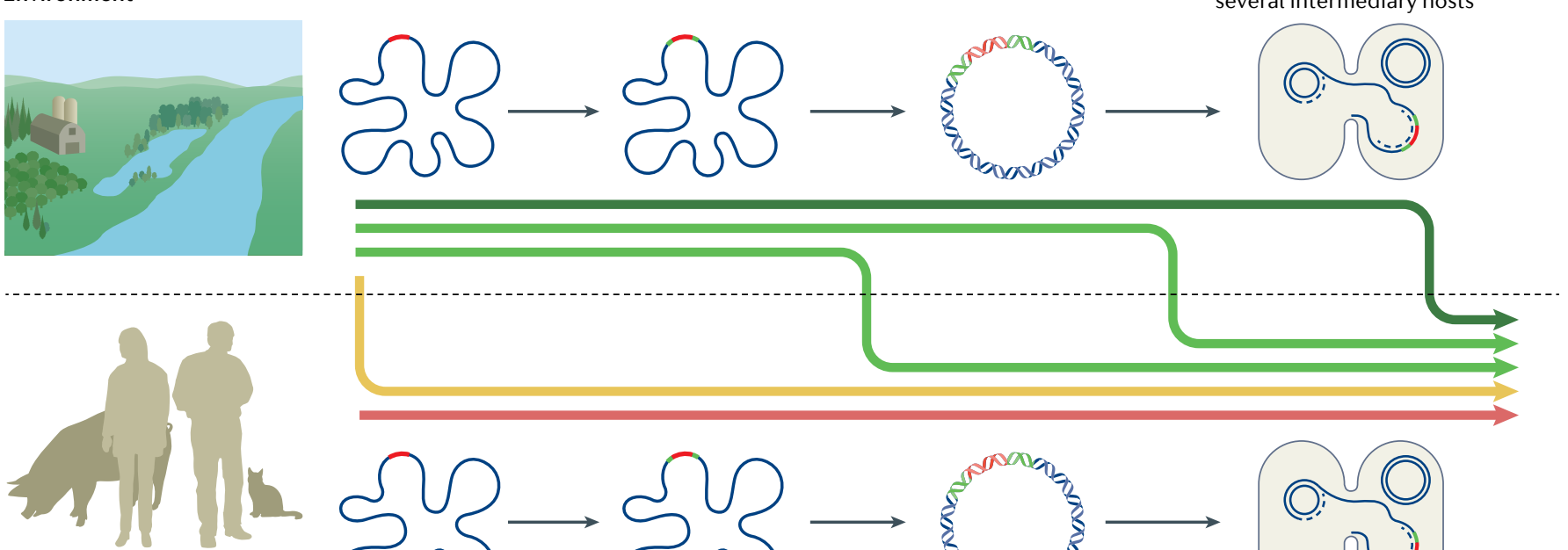

Human or animal microbiota
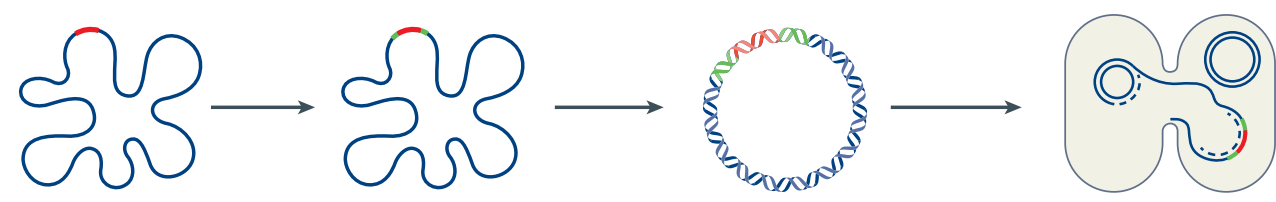

The source for the immobile ARG is a common member of the human or domestic animal microbiota. Mobilization and transfer to pathogens occur entirely within humans or animals

The source for the immobile ARG is a bacterium thriving in the external environment that sometimes enters the human or domestic animal microbiota. Mobilization and transfer to pathogens occur entirely within humans or animals

Fig. 1 | The role of the environment in the emergence of new resistance genes in pathogens. Conceptual illustration of how evolution leading to the emergence of a new antibiotic resistance gene (ARG; red) in pathogens can involve the environment and/or the human/domestic animal microbiota to different extents. The evolution typically occurs in steps, as indicated by the grey arrows. The first can be the association of a chromosomal ARG (red) with, for example, insertions sequences (ISs; green), which provide intracellular mobility. Intracellular relocation to, for example, a plasmid allows the ARG to move horizontally across strains and species. The mobilized ARG can then be transferred to a pathogen in one or several steps. In the most extreme cases, all genetic steps occur in either the environment (top) or in the human or domestic animal microbiota (bottom). However, at any stage bacteria carrying the ARG may move physically from the environment to the human
- The source for the immobile ARG is a bacterium thriving in the external environment. The ARG is mobilized in the environment (to variable degrees), but its final transfer to pathogens occurs within humans or domestic animals

- The source for the immobile ARG is a bacterium thriving in the external environment. Mobilization and transfer to pathogens occur entirely within the environment or domestic animal microbiota, as illustrated by the differently coloured, thick arrows. The genetic reservoir is considerably larger in the environment, suggesting that the source for new ARGs is often environmental bacteria. By contrast, reoccurring, strong antibiotic selection pressures and close contact with pathogens are more common in humans and domestic animals, although some external environments also share those drivers. Environmental release of faecal bacteria may also boost the evolutionary process by providing genetic elements that are adapted to capture and transfer ARGs. How common the different depicted scenarios are is still largely unknown. A better understanding of how often the different evolutionary steps occur in the environment versus the human or domestic animal microbiota and what drivers are most important would enable more efficient resource allocation to limit or delay the emergence of new ARGs in pathogens. 


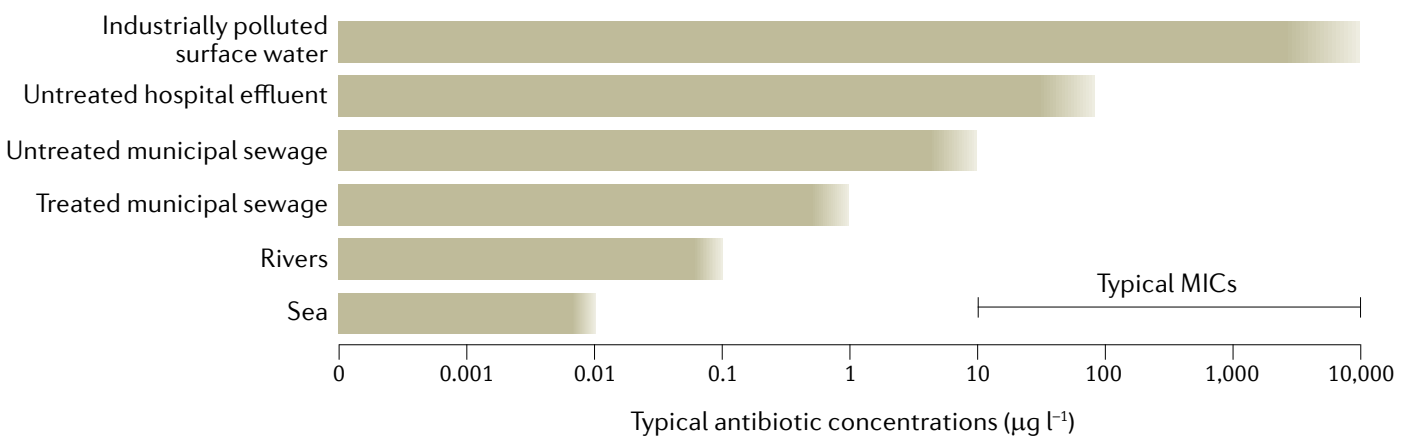

Fig. 2 | Antibiotic concentrations in selected aquatic environments. Different types of sources of antibiotic pollution typically give rise to different levels of exposure to aquatic bacterial communities. This, in turn, provides a reflection of the probability of environmental selection. Although very much a simplification, the ranges of typical antibiotic concentrations in aquatic environments exposed to excreted antibiotics from human use are depicted for the sea, rivers, treated and untreated municipal sewage effluents and untreated hospital effluents. Sea and river environments refer to those contaminated with treated municipal sewage. In addition, surface waters polluted directly by wastewater from drug manufacturing are included. As a comparison, typical minimal inhibitory concentrations (MICs) for many antibiotic-pathogen combinations often fall within the $10-10,000 \mathrm{\mu g}^{-1}$ range. As both depicted environmental concentrations and typical MICs are simplified illustrations representing many different antibiotics, an overlap between the two is not necessarily evidence of selection, unless there is overlap also for individual antibiotics. Note also that selection may occur at concentrations below the MIC.

plants $^{14,63}$ suggesting, but not proving, that antibiotic pollution plays a role in the evolution of resistance. Although some studies report increases in the relative abundance of certain ARGs in such environments, it is difficult to distinguish whether this is a result merely of taxonomic changes, unrelated to antibiotic selection pressures, or from direct selection of resistant strains within species ${ }^{6-68}$. Although plausible, definite evidence for such direct selection in sewage treatment plants is still lacking, and some evidence points to the opposite ${ }^{69}$. A recent study on sterile-filtered wastewaters indicated no selective effect of the investigated treated municipal effluent and a small selective effect by untreated influent. By contrast, untreated hospital wastewater strongly selected for multiresistant Escherichia coli in different controlled exposure experiments with individual isolates and communities ${ }^{70}$. The exact selective agents responsible therein could not be identified, but the relatively high levels of antibiotics in hospital wastewater make them plausible drivers of resistance selection.

The collective evidence for resistance selection in environments with very high levels of antibiotics (pollution from antibiotic manufacturing) is considerably stronger than that for excreted antibiotics. This is based on the exceedance of selective concentrations by orders of magnitude at industrially polluted $\operatorname{sites}^{58,60-62}$, increased relative abundance of resistant bacteria ${ }^{61,71}$, and considerable increases in the number of $\mathrm{ARGs}^{60,72}$, including previously unknown $\mathrm{ARGs}^{73}$, which are not accompanied by increases in faecal contamination ${ }^{65}$.

In solid or semi-solid media, such as sediments, soils, and sewage sludge, reported concentrations can often be much higher than in aqueous media ${ }^{51,55,74,75}$. Still, in most cases, only a minor fraction is bioavailable. Despite, for example, ciprofloxacin being found in sewage sludge at milligram per kilogram concentrations, ciprofloxacin-sensitive strains are very common in sludge $\mathrm{e}^{76,77}$, which suggests that the antibiotic is largely biologically unavailable here. Bioavailability in solid or semi-solid media can be inconsistent and depends strongly on physicochemical characteristics, including, for example, organic content and structure as well as the nature of the antibiotic ${ }^{78}$. Estimating the bioavailable fraction in such samples is challenging ${ }^{79}$, but genetically engineered reporter strains may provide a partial solution ${ }^{80}$.

Numerous studies have shown that the abundance of resistant bacteria and/or ARGs increase after manure from antibiotic-treated animals is added as a fertilizer to farmland. However, in many cases it is not possible to assign such increases to selective effects of antibiotic residues in the soil, as the added manure also carries resistant bacteria. In a recent study ${ }^{81}$, collected manure was spiked with antibiotics after collection, and the researchers observed selection of a fluorescently labelled Acinetobacter baylyi strain carrying a resistance plasmid compared with a similarly labelled non-resistant strain in the amended soil. Owing to the experimental design, it was possible to demonstrate within species selection by the antibiotics in the soil, although the study authors note that added antibiotic concentrations were higher than under normal fertilization regimens.

Metals and antibacterial biocides can, in many cases, co-select for antibiotic-resistant strains via cross-resistance (that is, via the same mechanism) or co-resistance (that is, via genetically linked mechanisms $)^{82,83}$. However, evidence suggests that it is the historical exposure to antibiotics, rather than metal or biocide exposure, that has led to the current co-occurrence of metal and biocide resistance genes and ARGs on plasmids, as abundant co-occurrence is largely restricted to communities that have been shaped by strong antibiotic selection pressures - the human and domestic animal microbiota $^{84}$. This does not exclude the possibility that metals and biocides could have an important role in maintaining strains that have already developed co-resistance, regardless of their prior evolutionary history. The concentrations needed for selection or co-selection are 
even less studied for metals and biocides, and need further attention. Some biocides can accelerate the rate of $\mathrm{HGT}^{42,85}$ as is the case for certain antibiotics ${ }^{43,86}$ and other pharmaceuticals ${ }^{87}$. Still, many naturally occurring stressors also accelerate $\mathrm{HGT}^{44}$. As stress-induced HGT is not a new phenomenon, it is unclear whether the induction of HGT by environmental pollutants has a discernible role in the rapid development of resistance in pathogens observed during the antibiotic era. Direct selection and co-selection are likely to be more critical.

Environmental contamination with faecal bacteria provides physical contact, and thus increased opportunities for gene exchange between resident environmental bacteria and bacteria adapted to the intestinal tract of human or domestic animals. Many intestinal bacteria are also known carriers of genetic elements (plasmids, integrative conjugative elements, insertion sequences,

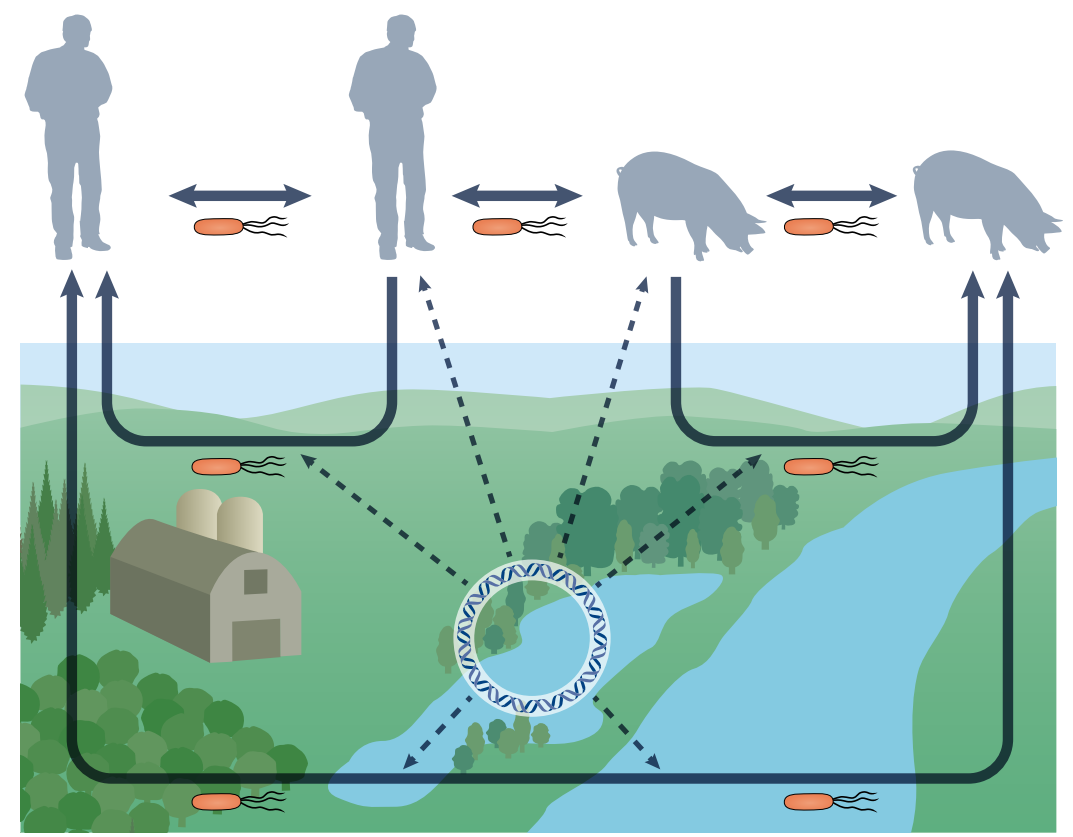

\begin{tabular}{|c|c|c|}
\hline $\begin{array}{l}\text { Transmission of pathogenic bacteria } \\
\text { between humans, between animals or } \\
\text { between humans and animals (either } \\
\text { direct or via the environment): }\end{array}$ & - - -> & $\begin{array}{l}\text { Uptake of new resistance factors } \\
\text { from the diverse environmental } \\
\text { microbiota: }\end{array}$ \\
\hline - Common & & - Relatively rare \\
\hline $\begin{array}{l}\text { - Risks are in principle quantifiable and } \\
\text { predictable }\end{array}$ & & - More challenging to predict \\
\hline $\begin{array}{l}\text { Consequences of each transmission } \\
\text { event are limited }\end{array}$ & & $\begin{array}{l}\text { - Consequences of single } \\
\text { transfer events may be vast }\end{array}$ \\
\hline - Transmission rates can be reduced & & - Irreversible \\
\hline
\end{tabular}

Fig. 3 | Pathways for transmission of bacterial pathogens and recruitment of resistance genes from the environmental microbiota. The dominating routes for transmission of (resistant) pathogens (solid arrows) are between humans, between domestic animals and sometimes between animals and humans. These transmission routes can be direct or indirect via the external environment (lower part of the figure), often through faecal contamination. The consequences of each transmission event are limited, and the risks are in principle quantifiable. There are also rarer and less predictable evolutionary events where new resistance factors are recruited to pathogens by horizontal gene transfer from the diverse, environmental microbiota (dashed arrows). Such transfer events may occur either in the environment or within the human or domestic animal microbiota. The consequences of single gene transfer events may be vast and are irreversible. transposons or integrons) that can facilitate the acquisition of genes and their transfer to pathogen ${ }^{88,89}$. Experiments with fluorescently labelled $E$. coli cells added to soils demonstrate their ability to rapidly acquire resistance determinants from the soil microbiota ${ }^{90}$.

In addition, it is also a possibility that ARGs present in faecal bacteria that are introduced into the environment could contribute to clinically relevant evolution of resistance by being transferred horizontally in one or several steps to pathogens, which might ultimately infect humans. However, the probability of these events lining up is likely to be much higher within the human or domestic animal microbiota, as selection pressures, commensals and pathogens are more commonly encountered together, and there are no environmental transmission barriers that need to be overcome ${ }^{91}$. We therefore argue that the clinical significance of resistance evolution resulting from the environmental release of ARGs that are already commonly encountered in the human microbiota is probably limited ${ }^{91}$.

\section{Environmental transmission}

The environment can provide a route for some resistant bacteria to colonize or infect hosts ${ }^{92-94}$. In this Review, we refer to this as a 'transmission event', whereas changes in their DNA sequence, including genetic transmission across bacterial species, are categorized as 'evolution events' (see earlier). For a resistant pathogen that is already widely circulating among humans, the consequence of a single transmission event to another individual is much more limited than for an evolutionary event leading to the emergence of a new, successful resistance genotype in pathogens, with potentially global consequences (FIG. 3). By contrast, wherever such transmission events become common, as is probably the case in many low- and middle income countries with inferior infrastructure for handling faecal waste (BOX 1), environmental transmission may have profound effects on the overall resistance situation ${ }^{95}$.

There is a vast literature on how certain resistant bacteria can spread via food and through contamination on surfaces, not the least in hospitals ${ }^{96}$. Exposure to surface waters heavily contaminated by faecal residues can also lead to various infections ${ }^{97}$. This has led, for example, to the bathing water directive in the European Union, which uses the levels of faecal indicator bacteria as surrogate exposure thresholds. It is plausible that resistant strains would have similar opportunities for transmission via contaminated water as sensitive strains of the same species. Accordingly, correlative analyses have suggested that the overall sanitation and waste infrastructure is a better predictor of national burdens of resistance than is the reported use of antibiotics ${ }^{95}$. Still, there are only a few dedicated studies indicating that environmental exposure could be important for colonization by and/or infection with specific resistant bacteria. A survey of faecal swabs from surfers from Britain, who are more likely to ingest seawater than non-surfers, found they were more prone to carry cephalosporin-resistant E. coli ${ }^{92}$. A different study found that recreational swimming might be a risk factor for urinary tract infections with extended-spectrum $\beta$-lactamase-producing $E$. coli 
or Klebsiella pneumoniae ${ }^{98}$. More studies of this type, in both high-income and low-income settings, are needed to estimate the role of contaminated water in the transmission of resistant bacteria.

Food, including raw vegetables, is another possible exposure route ${ }^{99}$. Infections caused by, for example, Salmonella spp., enterohaemorrhagic E. coli and Campylobacter jejuni as a result of consumption of contaminated fresh produce occur frequently ${ }^{100}$, but we are not aware of studies showing that consumers of contaminated produce have an increased probability of being colonized by resistant strains. However, it has been shown that fresh produce often carries various resistant bacteria with diverse mobile elements ${ }^{100-102}$. Hence, the safe use of human and animal faecal matter (manure, sludge and effluents from wastewater treatment plants) on farmland is warranted both to control transmission and to control resistance evolution ${ }^{103}$. Urban air can contain a high diversity of $\mathrm{ARGs}^{104}$, but there is very limited support for long-range aerial transmission of bacterial pathogens ${ }^{105}$.

The risks for transmission of resistant bacteria are, in principle, quantifiable and possible to model with data on environmental emissions, fate and exposure. Still, accurate models describing the environmental route are scarce $^{106,107}$. As the bacterial host and the genetic context of mobile ARGs are critical for transmission risks, models based on specific resistant bacteria are more likely to become predictive than are ARG-based models. A major knowledge gap is that we still do not know what doses are required for colonization by many bacteria.

The role of selective agents in environmental transmission, if any, is unclear. Although some pathogens (for example, Legionella spp. or Vibrio spp.) thrive in the environment, for most it is a more hostile environment than a human or domestic animal host. For those pathogens, growth in the environment is often limited. It is thus conceivable that small growth differences between resistant and non-resistant strains, caused by exposure to sub-MICs of antibiotics, are a minor determinant for the possibility that environmental exposure becomes sufficiently high for colonization or infection of a human or animal host. Other biotic and abiotic factors, such as temperature, oxygen pressure, nutrients, predation, and competition with other species, all unrelated to the antibiotic resistance profile of the bacteria, are likely to be much more important for environmental transmission opportunities for both resistant and non-resistant strains.

\section{The environment reflecting the clinic}

Although the environment contributes to the problem of antibiotic resistance, both during the evolution of resistance and as a transmission route, it can also provide means to manage it. Environmental microorganisms, including both fungi and bacteria, have been a source for many novel candidate antibiotic molecules, thereby advancing drug development ${ }^{108}$. In addition, there is continuous and widespread environmental emission of human- and animal-associated bacteria through different waste streams. Analysing the abundance and pattern of resistance in the environmental microbiota could therefore provide an opportunity to predict the regional resistance situation ${ }^{109-114}$ and indirectly also provide indications of historical antibiotic use ${ }^{115}$. This overlaps with the main objectives of classic, clinical resistance surveillance, which is critical for guiding empirical treatment, for evaluating interventions, and for identifying regional and temporal trends of resistance.

Although analyses of different environmental matrices may be informative of the regional resistance situation in humans or domestic animals, samples taken as close to the emission sources as possible are advantageous as they are more representative ${ }^{116}$. Monitoring of raw sewage is particularly promising for large-scale surveillance, at it contains pooled faecal bacteria from large populations. The possibility to screen bacteria from up to millions of people in the same sample makes the approach considerably less resource demanding than traditional surveillance of clinical isolates, a feature which would have a particularly high value in low-income regions ${ }^{116}$. The broad coverage also open opportunities to provide an 'early warning' for the emergence or early spread of rare resistance factors ${ }^{117,118}$, which would otherwise require extensive surveillance of individuals.

Several recent studies highlight the possibility of using sewage monitoring as a complement to clinical surveillance of resistance, either via phenotypic analyses of isolates ${ }^{110,111,113}$ or via analyses of ARGs ${ }^{112,114,119}$ via quantitative PCR or shotgun metagenomics. The latter is the method of choice of the Global Sewage Surveillance Project ${ }^{115}$, a large research initiative that covers more than 100 countries. The two approaches have distinct advantages and disadvantages (TABLE 1). For example, isolate-based sewage surveillance has a greater potential to inform empirical treatment than metagenomics, as only the former can provide species-specific phenotypic data with certainty, but the simplicity of metagenomics could make it attractive for monitoring regional and temporal trends in resistance ${ }^{112,119}$. Both approaches have advantages over traditional clinical surveillance as they cannot be linked to individuals, and hence the risk of ethical dilemmas is minimized ${ }^{112}$. Also, both approaches are easy to standardize, facilitating comparisons across time and space. Indeed, regional differences in strategies for when patient samples are collected for resistance determination may introduce substantial bias when comparisons are made with and between traditional surveillance datasets ${ }^{120}$.

Still, although resistance surveillance in sewage provides several benefits over traditional surveillance, more research and extensive benchmarking are required to understand the potential and limitations, and to bring this surveillance strategy into practical use. Lessons may be learned from sewage surveillance of poliovirus, which has been in place for decades ${ }^{121}$. Similarly, over the past year, numerous research groups across the world have monitored the dynamics of severe acute respiratory syndrome coronavirus 2 in sewage ${ }^{122,123}$, increasing the awareness of the approach.

\section{Studying resistance in the environment}

Quantitative analyses of ARGs, resistant bacteria and selective agents in environmental samples differ in terms of how informative data are for assessing risks for evolution or transmission, or as a reflection of the 
Table 1 | Comparison of sewage-based resistance surveillance with traditional clinical resistance surveillance

\begin{tabular}{|c|c|c|c|}
\hline Attribute & $\begin{array}{l}\text { Sewage-based resistance } \\
\text { surveillance (gene-based) }\end{array}$ & $\begin{array}{l}\text { Sewage-based resistance } \\
\text { surveillance (isolate-based) }\end{array}$ & $\begin{array}{l}\text { Clinical resistance surveillance } \\
\text { (isolate-based) }\end{array}$ \\
\hline $\begin{array}{l}\text { Potential bias comparing } \\
\text { trends over time and space }\end{array}$ & $\begin{array}{l}\text { Standardization of sampling easy, } \\
\text { enables comparisons with limited bias }\end{array}$ & $\begin{array}{l}\text { Standardization of sampling } \\
\text { easy, enables comparisons with } \\
\text { limited bias }\end{array}$ & $\begin{array}{l}\text { Differences in sampling strategies } \\
\text { often bias comparisons }\end{array}$ \\
\hline $\begin{array}{l}\text { Risk that the end points } \\
\text { studied are influenced by } \\
\text { a non-human bacterial } \\
\text { population }\end{array}$ & High risk & $\begin{array}{l}\text { Low to high risk depending on } \\
\text { species }\end{array}$ & No risk \\
\hline $\begin{array}{l}\text { Reflects intestinal carriage } \\
\text { or infections }\end{array}$ & $\begin{array}{l}\text { Reflects carriage, but may correlate } \\
\text { well with infection }\end{array}$ & $\begin{array}{l}\text { Reflects carriage, but may correlate } \\
\text { well with infection }\end{array}$ & $\begin{array}{l}\text { Reflects infection or carriage } \\
\text { depending on sample type }\end{array}$ \\
\hline $\begin{array}{l}\text { Reflects resistance in sick or } \\
\text { healthy part of population }\end{array}$ & $\begin{array}{l}\text { Reflects both, but to steer the focus, } \\
\text { surveillance may target municipal or } \\
\text { hospital sewage }\end{array}$ & $\begin{array}{l}\text { Reflects both, but to steer the focus, } \\
\text { surveillance may target municipal or } \\
\text { hospital sewage }\end{array}$ & $\begin{array}{l}\text { Reflects the resistance in people } \\
\text { who are infected and seek care }\end{array}$ \\
\hline Interpretation of numbers & $\begin{array}{l}\text { Represents the average abundance } \\
\text { of a selected gene or genes across the } \\
\text { faecal microbiota }\end{array}$ & $\begin{array}{l}\text { Represents the percentage of } \\
\text { carriers times the average proportion } \\
\text { of resistant strains within a species in } \\
\text { the faecal microbiota of the carriers }\end{array}$ & $\begin{array}{l}\text { Represents the percentage } \\
\text { of infected individuals or the } \\
\text { percentage of carriers depending } \\
\text { on the sample type }\end{array}$ \\
\hline $\begin{array}{l}\text { Identification of resistance } \\
\text { phenotypes }\end{array}$ & $\begin{array}{l}\text { Predicts resistance phenotypes broadly } \\
\text { from individual, acquired genes }\end{array}$ & Identifies resistance phenotypes & Identifies resistance phenotypes \\
\hline $\begin{array}{l}\text { Ability to link resistance } \\
\text { to species }\end{array}$ & $\begin{array}{l}\text { Difficult to link genes and thus } \\
\text { predicted resistances to specific } \\
\text { species }\end{array}$ & $\begin{array}{l}\text { Links resistance to specific } \\
\text { pathogen species }\end{array}$ & $\begin{array}{l}\text { Links resistance to specific } \\
\text { pathogen species }\end{array}$ \\
\hline $\begin{array}{l}\text { Ability to identify } \\
\text { multiresistance }\end{array}$ & $\begin{array}{l}\text { Does not enable the identification } \\
\text { of multiresistance patterns }\end{array}$ & Identifies multiresistance patterns & Identifies multiresistance patterns \\
\hline $\begin{array}{l}\text { Ability to identify rare types } \\
\text { of resistance }\end{array}$ & Possible via targeted analyses (PCR) & Possible via selective culturing & Challenging \\
\hline $\begin{array}{l}\text { Provides patient-specific } \\
\text { information }\end{array}$ & No & No & Yes \\
\hline $\begin{array}{l}\text { Ability to inform empirical } \\
\text { treatment }\end{array}$ & Unlikely & Possibly, after evaluation & Informs empirical treatment \\
\hline $\begin{array}{l}\text { Prospect for acceptance } \\
\text { in clinical community }\end{array}$ & $\begin{array}{l}\text { Very different from current surveillance, } \\
\text { major challenges }\end{array}$ & $\begin{array}{l}\text { Different from current surveillance, } \\
\text { but also bears similarities, } \\
\text { challenging }\end{array}$ & $\begin{array}{l}\text { The accepted standard among the } \\
\text { clinical community }\end{array}$ \\
\hline Ethical issues & No ethical issues with sampling & No ethical issues with sampling & $\begin{array}{l}\text { Ethical issues may arise when } \\
\text { carriers are identified }\end{array}$ \\
\hline Cost & Inexpensive & Rather inexpensive & Expensive \\
\hline $\begin{array}{l}\text { Simplicity of sample } \\
\text { collection and processing }\end{array}$ & Very simple sampling & $\begin{array}{l}\text { Simple, but more elaborate sampling } \\
\text { compared with gene-based sewage } \\
\text { surveillance }\end{array}$ & $\begin{array}{l}\text { Resource-demanding to process } \\
\text { samples from many individual } \\
\text { patients }\end{array}$ \\
\hline Need for many samples & $\begin{array}{l}\text { A single sample can (to some extent) } \\
\text { reflect the resistance situation in an } \\
\text { entire community }\end{array}$ & $\begin{array}{l}\text { A single sample can (to some extent) } \\
\text { reflect the resistance situation in an } \\
\text { entire community }\end{array}$ & $\begin{array}{l}\text { A large number of samples are } \\
\text { needed to reflect the resistance } \\
\text { situation }\end{array}$ \\
\hline $\begin{array}{l}\text { Need for calibration } \\
\text { against clinical resistance } \\
\text { prevalence }\end{array}$ & $\begin{array}{l}\text { More calibration against clinical } \\
\text { resistance needed }\end{array}$ & $\begin{array}{l}\text { More calibration against clinical } \\
\text { resistance needed }\end{array}$ & $\begin{array}{l}\text { Considered 'gold standard' } \\
\text { but suffers from, for example, } \\
\text { sampling bias }\end{array}$ \\
\hline $\begin{array}{l}\text { Need for development } \\
\text { of sampling protocol }\end{array}$ & $\begin{array}{l}\text { One sampling protocol covers all } \\
\text { enteric species (but without separation) }\end{array}$ & $\begin{array}{l}\text { Efficient, specific sampling method } \\
\text { evaluated for Escherichia coli, not yet } \\
\text { for other species }\end{array}$ & $\begin{array}{l}\text { Sampling method exists for almost } \\
\text { all bacterial pathogens }\end{array}$ \\
\hline $\begin{array}{l}\text { Need for local health care } \\
\text { infrastructure }\end{array}$ & $\begin{array}{l}\text { No local health care infrastructure } \\
\text { needed }\end{array}$ & $\begin{array}{l}\text { No local health care infrastructure } \\
\text { needed }\end{array}$ & $\begin{array}{l}\text { Local health care infrastructure } \\
\text { needed }\end{array}$ \\
\hline $\begin{array}{l}\text { Need for local sewage } \\
\text { collection system }\end{array}$ & Sewage collection system needed & Sewage collection system needed & $\begin{array}{l}\text { No sewage collection system } \\
\text { needed }\end{array}$ \\
\hline $\begin{array}{l}\text { Need for analytical } \\
\text { infrastructure }\end{array}$ & $\begin{array}{l}\text { Advanced infrastructure } \\
\text { (DNA sequencing, bioinformatic } \\
\text { competence) is needed, but can } \\
\text { be performed elsewhere }\end{array}$ & $\begin{array}{l}\text { Low-level to medium-level } \\
\text { technological analyses required } \\
\text { (culturing), can be done } \\
\text { independently in any standard } \\
\text { microbiology laboratory }\end{array}$ & $\begin{array}{l}\text { Low-level to medium-level } \\
\text { technological analyses required } \\
\text { (culturing), can be done } \\
\text { independently in any standard } \\
\text { microbiology laboratory }\end{array}$ \\
\hline
\end{tabular}

Sewage analyses with the objective to predict the regional, clinical resistance situation, based on either culture-independent analyses of genes (metagenomics or quantitative PCR arrays) or phenotypic resistance patterns of isolates, may provide an approach complementary to traditional, clinical, isolate-based resistance surveillance (compared from a conceptual point of view). 
regional clinical resistance situation. These distinct objectives are also best informed by analyses of different environmental matrices, as outlined recently ${ }^{116}$. Having such limitations in mind is critical for both designing and interpreting environmental surveillance studies. Findings of, for example, increased levels of ARGs can be a result of an on-site selection pressure, thereby indicating an increased risk of resistance evolution. When one is assessing evidence for on-site selection, any ARG, regardless of its clinical relevance, can be informative, as an antibiotic selection pressure would be expected to favour resistant strains of many species and ARGs in parallel. As an increased relative abundance of a species that tends to carry a given ARG can be unrelated to an antibiotic selection pressure, increased abundance of resistant strains over non-resistant strains within the same species adds to the evidence (see later). Increased levels of several ARGs providing resistance to the same antibiotic class, but less pronounced changes in the levels of ARGs providing resistance to other antibiotic classes, also supports a specific selection pressure as the driver behind their increase ${ }^{124}$. Alternatively, increased ARG abundances could be merely the result of faecal pollution ${ }^{104}$, which primarily would be informative about risks for transmission. Concurrent finding of selective agents at concentrations known to select for resistant bacteria in complex communities would support the former explanation and risk scenario, whereas high abundances of crAssphage, a bacteriophage that indicates human faecal pollution, would support the latter ${ }^{65}$. ARGs that occur predominantly in pathogens are also more informative about risks for transmission than those that tend to reside to a greater extent in non-pathogenic bacteria. Both aquatic and terrestrial environments polluted with residual faecal matter often harbour increased levels of ARGs ${ }^{65,125}$. Indeed, the spread of faecal material around the globe (for example, via sewage effluents, animal waste, and birds transporting bacteria from urban sites) has contributed to ARG contamination of almost the entire planet, including freshwater systems ${ }^{14,65,126}$, estuaries ${ }^{127}$, farmland soils ${ }^{128-130}$, arctic areas ${ }^{131,132}$, and $\operatorname{air}^{104,133}$, as a few examples.

Most bacterial species do not cause disease and are not associated with clinical breakpoint concentrations. Accordingly, environmental microbiologists most often define 'resistance' as a decreased susceptibility to an antibiotic compared with other strains of the same species. As most species of environmental bacteria are difficult to culture with standard methods ${ }^{134}$, environmental microbiologists, more often so than clinical microbiologists, also tend to study ARGs rather than resistant bacteria. It is important to appreciate the differences, particularly because the genetic context and host of the detected ARGs in most instances remain unknown. Linking ARGs to their hosts and/or mobile genetic element is often critical, both for assessing risks for evolution and transmission, and for predicting the resistance situation in the clinic from sewage analyses.

When feasible, cultivation-based approaches are still superior in terms of providing insights into both the phenotype and the context, particularly if combined with whole-genome sequencing. Long-read sequencing of DNA from bacterial communities might overcome some challenges in placing ARGs into context ${ }^{135}$, as short-read assemblies of ARG-containing contigs from complex metagenomes are notoriously uncertain. However, for plasmid-borne ARGs, other approaches are needed. EpicPCR (emulsion, paired isolation and concatenation PCR) could be applied to link plasmid-borne ARGs to hosts, but still sensitivity and specificity are limiting factors ${ }^{136}$. Another possible technology involves genomic crosslinking ${ }^{137}$. It should also be noted that detected ARGs in environmental samples may represent extracellular DNA ${ }^{138}$. Free DNA could potentially be taken up and incorporated in genomes, but compared with ARGs already present in living cells, the opportunities to propagate are still very small.

Shotgun metagenomics can be used to detect and quantify ARGs, with the main advantage over PCR being that any ARG present in available databases can be identified, also in retrospect. The chief disadvantage, even with short reads, is the limitation in sensitivity ${ }^{139}$. Quantitative PCR arrays can be a good compromise between coverage and sensitivity ${ }^{140}$. Analyses of other genetic elements or genes, such as the integrase of class 1 integrons, can often provide a good surrogate for the overall presence of anthropogenic pollution, including resistant bacteria in polluted environments ${ }^{141,142}$.

Characterizing the environmental resistome, particularly the already mobilized and thus more easily transferrable fraction, is important to understand the role of the environment as a source for new resistance factors. This includes understanding the host range and ecology of the vectors involved. Identifying those ARGs that are at risk of emerging or have just emerged in pathogens enables early detection in the clinic. Identifying such ARGs may also inform interventions to limit their spread, and enables gene-based diagnostics. Possibly, such knowledge could also guide future drug development by providing information on emerging resistance mechanisms ${ }^{143}$. Strategies to identify emerging resistance threats involve computational methods, including hidden Markov models ${ }^{27,29}$, as well as functional metagenomics screens ${ }^{26,144}$, which can be adapted to focus on already mobilized genetic elements ${ }^{36,117}$.

Environmental analyses of antibiotics advanced greatly in the past few decades; however, it can be challenging to accurately identify and quantify antibiotics that often occur at nanogram per litre levels in complex matrices ${ }^{53,145}$. The concentrations of antibiotics and other pharmaceuticals in sewage are usually reasonably stable over time, but can show diurnal patterns ${ }^{146}$. Emissions from production are often much more erratic and considerably more difficult to predict. This irregular discharge pattern was used in a recent study to attribute a large portion of various drugs found in a Swiss river to industrial emissions ${ }^{147}$. As antibiotics and resistant bacteria often have the same source (excreta from humans or domestic animals), correlations between the two in environmental samples provide, without additional data, very weak evidence for on-site selection by antibiotics. Study design and careful interpretation are therefore always key concerns. 


\section{Studying selection in the laboratory}

The basis for environmental risk assessments is to compare exposure levels (predicted or measured in the environment) with effect levels; that is, concentrations that are known or predicted to cause a certain response, most commonly derived from simplified laboratory experiments. The ultimate concern with antibiotic pollution is that it will contribute to the evolution of new, successful, resistant genotypes in pathogens, causing difficult-to-treat infections and eventually higher morbidity and mortality. This chain of events is very difficult to trace back, and also to study in controlled experiments. Therefore, analyses of selection pressures, being the most well recognized driver of resistance development, are commonly used as surrogates for risk. However, it is possible that even evident selection pressures have no or little contribution to the end points of ultimate concern. Note that it is not yet exactly known for any ARG in what place, in what environment or under what conditions the ARG was mobilized or transferred to a pathogen for the first time. Hence, any actions to reduce selection pressures to mitigate the risk of emergence of new forms of resistance, whether in humans, animals or the environment, are based on the precautionary principle.

How to best assess the selective potential of antibiotics and co-selective agents in the environment is still an open question. Although the most critical form of selection for the evolution of resistance is between strains within species (largest niche overlap), transmission risks for a given resistant pathogen can increase as a consequence of both within-species and between-species selection. This should ideally be taken into account when one is designing assays for environmental selection and defining environmental selective concentrations. Assays based on analyses of ARGs may be sensitive but can rarely distinguish within-species selection from between-species selection with certainty, and should therefore be interpreted with some caution. Similar concerns apply to culture-based analyses where bacteria are not identified to the species level. Although single-species competition experiments are simple and easier to reproduce, they may not reflect the situation in more complex communities ${ }^{148}$. Culture-based assays often suffer from only one or a few species within a community being studied at a time. Still, culture-based assays, where the proportion of resistant bacteria within species in complex communities is studied, are probably the most relevant, but not necessarily the most sensitive, approach ${ }^{149}$.

Minimal selective concentrations (MSC) is an extrapolation of generated competition data, reflecting the concentration at which cost and benefit are predicted to be balanced ${ }^{64}$. If costs are very low, the estimation of cost, the estimation of balancing benefits and thus estimates of the MSC become more sensitive to noise. The confidence interval associated with such estimates could be high ${ }^{150}$ unless there is good replication around the MSC. The generation of lowest observed effect concentrations (LOECs) and the corresponding no observed effect concentrations (NOECs) for resistance selection are in that sense more robust measures.

A simplified approach to generate predicted no effect concentrations (PNECs) for resistance selection from available MICs assumes that selection must occur in at least some communities at the lowest reported or predicted MIC for a given antibiotic. The proposed approach ${ }^{63}$ has rapidly been applied widely, also in regulatory ${ }^{151}$ and industrial ${ }^{152}$ initiatives to curb risks for selection in the environment. There is potential to refine MSC predictions from MICs by taking into account also the shape of the dose-response curves ${ }^{153}$. Recently, it was also proposed that LOECs and NOECs for resistance selection could be based on the lowest concentration that affects growth of entire communities ${ }^{154}$. From a theoretical point of view, the lowest concentration affecting growth of any species in a community represents the lower boundary for possible resistance selection. But as overall community growth was assessed rather than the growth of individual strains, reduced growth of some strains could easily be compensated by other strains growing more rapidly. Nor would lowered growth of any but the most abundant strains be easy to detect, leading to limited sensitivity of such assays.

For most widely circulating ARGs, the costs are indeed low in the contexts in which they have become adapted, otherwise the resistant strains would disappear very quickly as soon as antibiotic exposure ceases ${ }^{155}$. As costs are strongly dependent on the genetic context, the presence of other strains and species in a community, and abiotic factors, it is difficult to set up tests that accurately reflect costs for a broader set of contexts and exposure scenarios. A recent study ${ }^{149}$ accordingly proposed basing concentration thresholds preventing environmental selection solely on the lowest concentration that provides a benefit to resistant strains, ignoring costs in the given test system. This may be achieved by comparing ratios of resistant strains versus non-resistant strains after exposure to different concentrations of antibiotics (given that costs are independent of the exposure concentration), rather than comparing ratios before exposure with those after exposure. Another study ${ }^{156}$ came to a similar conclusion on how to derive concentration thresholds, but not from the standpoint that costs are context dependent; the study authors argued that even if costs are not fully compensated, the persistence of resistant strains, and hence risks for transmission, would increase. Although we agree with the principle, we believe that other abiotic and biotic factors that determine the survival of most pathogens in environmental media, and hence exposure opportunities, are likely to be of much greater importance for transmission risks (see the section entitled "Environmental transmission").

\section{Outlook}

The environment has a role both in evolution and transmission of resistance, possibly more so than has generally been recognized ${ }^{11-16}$. A remaining and pressing knowledge gap is our limited understanding of where and under what circumstances the critical steps occur that lead to the emergence of new forms of resistance in clinically important bacteria. Exploring the recent history of resistance factors that already have become clinical problems is one possible strategy to reveal patterns and enable generalizations ${ }^{49}$. Future genome sequencing of many more environmental species is likely 
to provide a much better foundation for such investigations. Understanding the role of pollution with selective agents in the emergence and evolution of resistance is particularly important, as neglecting an important driver could have major health consequences. A major knowledge gap is still what role the low or moderately high levels of excreted antibiotics have, and what methods are most suitable to reflect risks for environmental selection. This is in contrast to high-level industrial antibiotic pollution, for which many stakeholders already consider the risks unacceptable, and the core challenge now is rather how to accomplish change ${ }^{157}$. The use of antibiotics on crops is only rarely studied ${ }^{158}$, but could potentially be a source of very high concentrations, particularly in lowand middle-income countries ${ }^{57}$. With regard to risks for transmission, we know considerably more about the flow of resistant bacteria to the environment than to what extent resistant bacteria from environmental sources lead to colonization and disease.

On the basis of current evidence, many policymakers advocate the precautionary principle and call for actions to reduce exposures ${ }^{17-21}$. At the same time, actions to reduce pollution on a broad scale are expected to be both difficult and expensive, making prioritization necessary. Shaping mitigation strategies places additional demands on recognizing what is feasible from, for example, political, economic and geographical standpoints. It is also important to identify which actors can drive appropriate mitigations, including what their specific incentives and counterincentives for actions are $\mathrm{e}^{157}$. While not neglecting the technological needs involved, creating socio-economic and legal drivers for change is often even more challenging. To reduce discharges from antibiotic manufacturing, a number of such actions either were initiated recently or have been proposed by governments ${ }^{151,159-161}$ or multinational organizations, such as the European Union ${ }^{20}$, the G7 (REF. ${ }^{162}$ ), the United Nations Environment Programme ${ }^{17}$, and the Word Health Organization, the World Organisation for Animal Health and the Food and Agriculture Organization of the United Nations ${ }^{21}$. These include pollution control as an award criterion in procurement processes ${ }^{20,160,161}$ and decisions on which products to subsidize ${ }^{159}$, demanding increased transparency on production sites and emission levels to increase accountability ${ }^{20,163}$, amending pollution control in the framework for good manufacturing practice ${ }^{162}$, and applying legally binding limits for discharges ${ }^{151}$. Many pharmaceutical companies also acknowledge the need for change and have collectively endorsed voluntary emission targets ${ }^{63,152}$. Although this must be seen as a positive initiative, the near-complete lack of disclosure of both production sites for active ingredients and emission levels ${ }^{18}$ makes it difficult to judge progress, reinforcing that industrial pollution is rarely resolved without active interference from public institutions.
On the technical side, installing basic treatment of waste streams, whether industrial, municipal or from animal sources, should have high priority as it addresses many types of risks, not the least substantial transmission risks for several pathogens (including resistant bacteria) and deterioration of valuable water resources $^{164}$. Additional treatment of wastewaters with more advanced methods (such as ozonation or activated carbon) is a second step that would remove not only many selective agents but also a large range of additional contaminants ${ }^{165}$. Hence, an important motivation for more advanced treatment, particularly of municipal wastewater, is the 'collateral benefit' such treatment can provide by reducing the risks of many pollutants, known and unknown ones.

Measures to limit the risk for transmission of antibioticresistant bacteria could involve both reducing emissions to the environment and/or reducing exposure ${ }^{166}$. Such actions often coincide with measures to reduce infections in general. Given what is at stake, there could be good reasons also to take specific actions to reduce the risk for evolution of resistance, despite large uncertainties. To mitigate such risks, we ought to prioritize actions where risks are high and where changes can feasibly be achieved in a limited time frame. Prioritization should ideally be done on a global level, as the consequences of inaction will affect everyone in the long run, regardless of where a resistance factor emerges. Radically reducing emissions of exceptionally high concentrations from drug manufactures is one such apparent starting point ${ }^{17,19,59}$.

To assign appropriate measures to reduce the risk of resistance evolution associated with human waste streams, it is critical to understand where selection primarily occurs (hospital sewers, community sewers, wastewater treatment plants, recipients and so on). In contrast to managing risks with most other pollutants, the relevant protection target related to antibiotic resistance development is bacteria, rather than (aquatic) wildlife or humans. Sewers and wastewater treatment plant environments harbour dense, complex bacterial communities that often include pathogens. Furthermore, as antibiotic levels are often higher than in receiving waters, they may be more likely a spawning ground for resistance evolution than the recipient waterways. Measures with the intention to control resistance selection should therefore also take into account risks for selection that occur before discharge of the wastewater.

Sewage epidemiology is still in its infancy, at least with regard to how well the regional clinical resistance situation can be predicted. It is critical to benchmark environmental resistance data, whether based on isolates or metagenomes, against high-quality clinical data. Still, it may take more than evidence of good correlations to bring environmental analyses of resistance into clinical policy.

Published online 4 November 2021
1. D'Costa, V. M. et al. Antibiotic resistance is ancient. Nature 477, 457-461 (2011).

This study shows that different ARGs are present in 30,000-year-old permafrost.

2. Bhullar, K. et al. Antibiotic resistance is prevalent in an isolated cave microbiome. PLoS ONE 7, e34953 (2012).
3. Lugli, G. A. et al. Ancient bacteria of the Ötzi's microbiome: a genomic tale from the Copper Age. Microbiome 5, 5 (2017)

4. Perry, J., Waglechner, N. \& Wright, G. The prehistory of antibiotic resistance. Cold Spring Harb. Perspect. Med. 6, a025197 (2016).
5. Davies, J. \& Davies, D. Origins and evolution of antibiotic resistance. Microbiol. Mol. Biol. Rev. 74 . 417-433 (2010)

This authoritative and educational review discusses in an insightful way the evolution of resistance, including its origins and future implications. 
6. Allen, H. K. et al. Call of the wild: antibiotic resistance genes in natural environments. Nat. Rev. Microbiol 8 251-259 (2010).

7. Martinez, J. L. The role of natural environments in the evolution of resistance traits in pathogenic bacteria. Proc. R. Soc. B Biol. Sci. 276, 2521-2530 (2009).

8. Alcock, B. P. et al. CARD 2020: antibiotic resistome surveillance with the comprehensive antibiotic resistance database. Nucleic Acids Res. https://doi.org/ 10.1093/nar/gkz935 (2019).

9. Mackenzie, J. S. \& Jeggo, M. The one health approach - why is it so important? Trop. Med. Infect. Dis. 4, 88 (2019)

10. Buschhardt, T. et al. A one health glossary to support communication and information exchange between the human health, animal health and food safety sectors. One Health 13, 100263 (2021).

11. Berendonk, T. U. et al. Tackling antibiotic resistance: the environmental framework. Nat. Rev. Microbiol. 13, 310-317 (2015)

12. Wellington, E. M et al. The role of the natural environment in the emergence of antibiotic resistance in gram-negative bacteria. Lancet Infect. Dis. 13, 155-165 (2013)

13. Bengtsson-Palme, J., Kristiansson, E. \& Larsson, D. G. J. Environmental factors influencing the development and spread of antibiotic resistance. FEMS Microbiol. Rev. https://doi.org/10.1093/femsre/fux053 (2017).

14. Chow, L. K. M., Ghaly, T. M. \& Gillings, M. R. A survey of sub-inhibitory concentrations of antibiotics in the environment. J. Environ. Sci. 99 21-27 (2021)

15. Andersson, D. I. et al. Antibiotic resistance: turning evolutionary principles into clinical reality. FEMS Microbiol. Rev. 44, 171-188 (2020).

16. Singer, A. C., Shaw, H., Rhodes, V. \& Hart, A. Review of antimicrobial resistance in the environment and its relevance to environmental regulators. Front. Microbiol. https://doi.org/10.3389/ fmicb.2016.01728 (2016)

17. United Nations Environment Programme. Frontiers 2017: emerging issues of environmental concern, https://www.unenvironment.org/resources/frontiers2017-emerging-issues-environmental-concern (2017).

18. Access to Medicines Foundation. 2020 antimicrobial resistance benchmark, https:// accesstomedicinefoundation.org/publications/ 2020-antimicrobial-resistance-benchmark (2020).

19. Review on Antimicrobial Resistance. Antimicrobials in agriculture and the environment: reducing unnecessary waste, https://amr-review.org/ Publications.html (2015)

20. European Parliament. Strategic approach to pharmaceuticals in the environment, https://www. europarl.europa.eu/doceo/document/TA-9-20200226_EN.pdf (2020).

21. WHO. Technical brief on water, sanitation, hygiene (WASH) and wastewater management to prevent infections and reduce the spread of antimicrobial resistance (AMR)., https://www.who.int/water_ sanitation health/publications/wash-wastewatermanagement-to-prevent-infections-and-reduce-amr/en/ (2020).

22. Graham, D. W. et al. Complexities in understanding antimicrobial resistance across domesticated animal, human, and environmental systems. Ann. N. Y. Acad. Sci. 1441, 17-30 (2019).

23. Smalla, K., Cook, K., Djordjevic, S. P., Klümper, U. \& Gillings, M. Environmental dimensions of antibiotic resistance: assessment of basic science gaps. FEMS Microbiol. Ecol. https://doi.org/10.1093/ femsec/fiy 195 (2018)

24. Rinke, C. et al. Insights into the phylogeny and coding potential of microbial dark matter. Nature 499, 431-437 (2013).

25. Schulz, F. et al. Towards a balanced view of the bacterial tree of life. Microbiome https://doi.org 10.1186/s40168-017-0360-9 (2017)

26. Forsberg, K. J. et al. The shared antibiotic resistome of soil bacteria and human pathogens. Science 337 1107-1111 (2012).

This study demonstrates numerous identical resistance gene loci between multiresistant soil bacteria and diverse human pathogens, providing evidence for recent gene exchange across species and environments.

27. Berglund, F. et al. Identification of 76 novel B 1 metallo-beta-lactamases through large-scale screening of genomic and metagenomic data. Microbiome 5, 134 (2017).
28. Dantas, G., Sommer, M. O. A., Oluwasegun, R. D $\&$ Church, G. M. Bacteria subsisting on antibiotics. Science 320, 100-103 (2008)

29. Berglund, F. et al. Comprehensive screening of genomic and metagenomic data reveals a large diversity of tetracycline resistance genes. Microb. Genomics https://doi.org/10.1099/mgen.0.000455 (2020).

30. Pawlowski, A. C. et al. A diverse intrinsic antibiotic resistome from a cave bacterium. Nat. Commun. 7 , 13803 (2016).

31. Morar, M. \& Wright, G. D. The genomic enzymology of antibiotic resistance. Annu. Rev. Genet. 44, 25-51 (2010).

32. Andersson, D. I., Jerlström-Hultqvist, J. \& Näsvall, J. Evolution of new functions de novo and from preexisting genes. Cold Spring Harb. Perspect. Biol. 7, a017996 (2015)

33. Razavi, M., Kristiansson, E., Flach, C.-F. \& Larsson, D. G. J. The association between insertion sequences and antibiotic resistance genes. $m S p h e r e$ https://doi.org/10.1128/msphere.00418-20 (2020).

34. Partridge, S. R., Kwong, S. M., Firth, N. \& Jensen, S. O. Mobile genetic elements associated with antimicrobial resistance. Clin. Microbiol. Rev. https://doi.org/10.1128/cmr.00088-17 (2018).

35. Gillings, M. et al. The evolution of class 1 integrons and the rise of antibiotic resistance. J. Bacteriol. 190 5095-5100 (2008)

36. Razavi, M. et al. Discovery of the fourth mobile sulfonamide resistance gene. Microbiome https:/ doi.org/10.1186/s40168-017-0379-y (2017).

37. Flach, C.-F. et al. Does antifouling paint select for antibiotic resistance? Sci. Total Environ. 590-591, 461-468 (2017)

38. Shintani, M. et al. Plant species-dependent increased abundance and diversity of IncP-1 plasmids in the rhizosphere: new insights into their role and ecology. Front. Microbiol. 11, 590776 (2020)

39. Baquero, F., Coque, T. M., Martínez, J.-L., Aracil-Gisbert, S. \& Lanza, V. F. Gene transmission in the one health microbiosphere and the channels of antimicrobial resistance. Front. Microbiol. https://doi.org/10.3389/fmicb.2019.02892 (2019).

40. Vandecraen, J., Chandler, M., Aertsen, A. \& Van Houdt, R. The impact of insertion sequences on bacterial genome plasticity and adaptability. Crit. Rev. Microbiol. 43, 709-730 (2017).

41. Depardieu, F., Podglajen, I., Leclercq, R., Collatz, E. $\&$ Courvalin, P. Modes and modulations of antibiotic resistance gene expression. Clin. Microbiol. Rev. 20 79-114 (2007).

42. Jutkina, J., Marathe, N. P., Flach, C. F. \& Larsson, D. G. J. Antibiotics and common antibacterial biocides stimulate horizontal transfer of resistance at low concentrations. Sci. Total Environ. 616-617, 172-178 (2018)

43. Scornec, H., Bellanger, X., Guilloteau, H., Groshenry, C $\&$ Merlin, C. Inducibility of Tn916 conjugative transfer in Enterococcus faecalis by subinhibitory concentrations of ribosome-targeting antibiotics. J. Antimicrob. Chemother. 72, 2722-2728 (2017).

44. Aminov, R. I. Horizontal gene exchange in environmental microbiota. Front. Microbiol. https://doi.org/10.3389/fmicb.2011.00158 (2011).

45. Knöppel, A., Näsvall, J. \& Andersson, D. I. Evolution of antibiotic resistance without antibiotic exposure. Antimicrob. Agents Chemother. https://doi.org/ 10.1128/aac.01495-17 (2017).

46. Kimura, M. \& Ohta, T. The average number of generations until fixation of a mutant gene in a finite population. Genetics 61, 763-771 (1969).

47. Letten, A. D., Hall, A. R. \& Levine, J. M. Using ecological coexistence theory to understand antibiotic resistance and microbial competition. Nat. Ecol. Evol. 5, 431-441 (2021)

48. Waglechner, N. \& Wright, G. D. Antibiotic resistance: it's bad, but why isn't it worse? BMC Biol. https://doi.org/10.1186/s1 2915-017-0423-1 (2017).

49. Ebmeyer, S., Erik, K. \& Larsson, D. G. J. A framework for identifying the recent origins of mobile antibiotic resistance genes. Commun. Biol. https://doi.org/ 10.1038/s42003-020-01545-5 (2021). This study amends, summarizes and scrutinizes current evidence for proposed recent origin species for mobile ARGs.

50. Andersson, D. I. \& Hughes, D. Persistence of antibiotic resistance in bacterial populations. FEMS Microbiol. Rev. 35, 901-911 (2011).

51. Wang, J., Chu, L., Wojnárovits, L. \& Takács, E. Occurrence and fate of antibiotics, antibiotic resistant genes (ARGs) and antibiotic resistant bacteria (ARB) in municipal wastewater treatment plant: an overview. Sci. Total. Environ. 744, 140997 (2020).

52. Tran, N. H., Reinhard, M. \& Gin, K. Y.-H. Occurrence and fate of emerging contaminants in municipal wastewater treatment plants from different geographical regions-a review. Water Res. 133, 182-207 (2018).

53. Szymańska, U. et al. Presence of antibiotics in the aquatic environment in Europe and their analytical monitoring: recent trends and perspectives. Microchem. J. 147, 729-740 (2019).

54. Anwar, M., Iqbal, Q. \& Saleem, F. Improper disposal of unused antibiotics: an often overlooked driver of antimicrobial resistance. Expert Rev. Antiinfect Ther. https://doi.org/10.1080/14787210.2020.1754797 (2020).

55. Cabello, F. C. et al. Antimicrobial use in aquaculture re-examined: its relevance to antimicrobial resistance and to animal and human health. Environ. Microbiol. 15, 1917-1942 (2013)

56. Cabello, F. C., Godfrey, H. P., Buschmann, A. H. \& Dölz, H. J. Aquaculture as yet another environmental gateway to the development and globalisation of antimicrobial resistance. Lancet Infect. Dis. 16, e127-e133 (2016)

57. Taylor, P. \& Reeder, R. Antibiotic use on crops in low and middle-income countries based on recommendations made by agricultural advisors. CABI Agric. Biosci. https://doi.org/10.1186/s43170-020-00001-y (2020).

58. Larsson, D. G. J. Pollution from drug manufacturing: review and perspectives. Philos. Trans. R. Soc. B Biol. Sci. 369, 20130571 (2014).

59. Larsson, D. G. J., De Pedro, C. \& Paxeus, N. Effluent from drug manufactures contains extremely high levels of pharmaceuticals. J. Hazard. Mater. 148, 751-755 (2007).

60. Milaković, M. et al. Pollution from azithromycinmanufacturing promotes macrolide-resistance gene propagation and induces spatial and seasonal bacterial community shifts in receiving river sediments. Environ. Int. 123, 501-511 (2019).

61. Bielen, A. et al. Negative environmental impacts of antibiotic-contaminated effluents from pharmaceutical industries. Water Res. 126, 79-87 (2017).

62. Fick, J. et al. Contamination of surface, ground, and drinking water from pharmaceutical production. Environ. Toxicol. Chem. 28, 2522-2527 (2009).

63. Bengtsson-Palme, J. \& Larsson, D. G. J. Concentrations of antibiotics predicted to select for resistant bacteria: proposed limits for environmental regulation. Environ. Int. 86, 140-149 (2016). This study uses a simplified approach based on available MIC data for many species to predict concentrations of 111 antibiotics that are not likely to select for resistance.

64. Gullberg, E. et al. Selection of resistant bacteria at very low antibiotic concentrations. PLoS Pathog. 7 e1002158 (2011).

65. Karkman, A., Pärnänen, K. \& Larsson, D. G. J. Fecal pollution can explain antibiotic resistance gene abundances in anthropogenically impacted environments. Nat. Commun. https://doi.org/10.1038/ s41467-018-07992-3 (2019).

66. Yang, Y., Li, B., Zou, S., Fang, H. H. P. \& Zhang, T. Fate of antibiotic resistance genes in sewage treatment plant revealed by metagenomic approach. Water Res. 62, 97-106 (2014).

67. Bengtsson-Palme, J. et al. Elucidating selection processes for antibiotic resistance in sewage treatment plants using metagenomics. Sci. Total Environ. 572, 697-712 (2016)

68. Manaia, C. M. et al. Antibiotic resistance in wastewater treatment plants: tackling the black box. Environ. Int. 115, 312-324 (2018).

69. Flach, C. F., Genheden, M., Fick, J. \& Joakim Larsson, D. G. A comprehensive screening of Escherichia coli isolates from Scandinavia's largest sewage treatment plant indicates no selection for antibiotic resistance. Environ. Sci. Technol. 52 11419-11428 (2018).

70. Kraupner, N. et al. Evidence for selection of multiresistant E. coli by hospital effluent. Environ. Int. 150 106436 (2021).

71. Flach, C. F. et al. Isolation of novel IncA/C and IncN fluoroquinolone resistance plasmids from an antibiotic-polluted lake. J. Antimicrob. Chemother 70, 2709-2717 (2015)

72. Bengtsson-Palme, J., Boulund, F., Fick, J., Kristiansson, E. \& Larsson, D. G. J. Shotgun metagenomics reveals a wide array of antibiotic resistance genes and mobile elements in a polluted lake in India. Front. Microbiol. https://doi.org/ 10.3389/fmicb.2014.00648 (2014). 
73. Marathe, N. P. et al. Functional metagenomics reveals a novel carbapenem-hydrolyzing mobile beta-lactamase from Indian river sediments contaminated with antibiotic production waste. Environ. Int. 11 2, 279-286 (2018).

74. Thiele-Bruhn, S. Pharmaceutical antibiotic compound in soils-a review. J. Plant Nutr. Soil Sci. 166, 145-167 (2003)

75. Li, W., Shi, Y., Gao, L., Liu, J. \& Cai, Y. Occurrence, distribution and potential affecting factors of antibiotics in sewage sludge of wastewater treatment plants in China. Sci. Total. Environ. 445-446 306-313 (2013).

76. Reinthaler, F. F. et al. Resistance patterns of Escherichia coli isolated from sewage sludge in comparison with those isolated from human patients in 2000 and 2009. J. Water Health 11, 13-20 (2013).

77. Rutgersson, C. et al. Long-term application of Swedish sewage sludge on farmland does not cause clear changes in the soil bacterial resistome. Environ. Int. 137, 105339 (2020).

78. Jechalke, S., Heuer, H., Siemens, J., Amelung, W. \& Smalla, K. Fate and effects of veterinary antibiotics in soil. Trends Microbiol. 22, 536-545 (2014).

79. Boxall, A. B. et al. Pharmaceuticals and personal care products in the environment: what are the big questions? Environ. Health Perspect. 120, 1221-1229 (2012)

80. Song, J., Rensing, C., Holm, P. E., Virta, M. \& Brandt, K. K. Comparison of metals and tetracycline as selective agents for development of tetracycline resistant bacterial communities in agricultural soil. Environ. Sci. Technol. 51, 3040-3047 (2017).

81. Jechalke, S. et al. Plasmid-mediated fitness advantage of Acinetobacter baylyi in sulfadiazine-polluted soil. FEMS Microbiol. Lett. 348, 127-132 (2013). This study shows that a commonly used antibiotic in pig farming has the potential to select for a resistant Acinetobacter strain in manure-amended soils.

82. Pal, C et al. Metal resistance and its association with antibiotic resistance. Adv. Microb. Physiol. 70, 261-313 (2017).

83. Wales, A. \& Davies, R. Co-selection of resistance to antibiotics, biocides and heavy metals, and its relevance to foodborne pathogens. Antibiotics 4 , 567-604 (2015)

84. Pal, C., Bengtsson-Palme, J., Kristiansson, E. \& Larsson, D. G. J. Co-occurrence of resistance genes to antibiotics, biocides and metals reveals novel insights into their co-selection potential. BMC Genomics https://doi.org/10.1186/s12864. 015-2153-5 (2015)

85. Klümper, U. et al. Metal stressors consistently modulate bacterial conjugal plasmid uptake potential in a phylogenetically conserved manner. ISME J. 11 152-165 (2017)

86. Jutkina, J., Rutgersson, C., Flach, C. F. \& Joakim Larsson, D. G. An assay for determining minimal concentrations of antibiotics that drive horizontal transfer of resistance. Sci. Total. Environ. 548-549, 131-138 (2016)

87. Wang, Y. et al. Non-antibiotic pharmaceuticals enhance the transmission of exogenous antibiotic resistance genes through bacterial transformation. ISME J. 14, 2179-2196 (2020).

88. Klumper, U. et al. Broad host range plasmids can invade an unexpectedly diverse fraction of a soil bacterial community. ISME J. 9, 934-945 (2015). This study shows that plasmids that are common in pathogens can easily be taken up by diverse environmental bacteria, thereby providing pathways for the exchange of resistance genes.

89. Gillings, M. R., Paulsen, I. T. \& Tetu, S. G. Genomics and the evolution of antibiotic resistance. Ann. N. Y. Acad. Sci. 1388, 92-107 (2017).

90. Heuer, H. \& Smalla, K. Plasmids foster diversification and adaptation of bacterial populations in soil. FEMS Microbiol. Rev. 36, 1083-1104 (2012).

91. Bengtsson-Palme, J. \& Larsson, D. G. Antibiotic resistance genes in the environment: prioritizing risks. Nat. Rev. Microbiol. 13, 396 (2015).

92. Leonard, A. F. C. et al. Exposure to and colonisation by antibiotic-resistant E. coli in UK coastal water users: environmental surveillance, exposure assessment, and epidemiological study (Beach Bum Survey). Environ. Int. 114, 326-333 (2018). This is one of few studies showing that people more likely to ingest surface waters are also more prone to be carriers of resistant bacteria compared with matched controls.
93. Manaia, C. M. Assessing the risk of antibiotic resistance transmission from the environment to humans: non-direct proportionality between abundance and risk. Trends Microbiol. 25, 173-181 (2017).

94. Schijven, J. F., Blaak, H., Schets, F. M. \& De Roda Husman, A. M. Fate of extended-spectrum $\beta$-lactamase-producing Escherichia coli from faecal sources in surface water and probability of human exposure through swimming. Environ. Sci. Technol. 49, 11825-11833 (2015)

95. Collignon, P., Beggs, J. J., Walsh, T. R., Gandra, S. \& Laxminarayan, R. Anthropological and socioeconomic factors contributing to global antimicrobial resistance: a univariate and multivariable analysis. Lancet Planet. Health 2, e398-e405 (2018).

96. Dancer, S. J. Controlling hospital-acquired infection: focus on the role of the environment and new technologies for decontamination. Clin. Microbiol. Rev. 27, 665-690 (2014)

97. Weber, D. J., Anderson, D. \& Rutala, W. A. The role of the surface environment in healthcare-associated infections. Curr. Opin. Infect. Dis. 26, 338-344 (2013).

98. Søraas, A., Sundsfjord, A., Sandven, I., Brunborg, C. $\&$ Jenum, P. A. Risk factors for community-acquired urinary tract infections caused by ESBL-producing Enterobacteriaceae -a case-control study in a low prevalence country. PLOS ONE 8, e69581 (2013).

99. Zhou, S.-Y.-D. et al. Prevalence of antibiotic resistome in ready-to-eat salad. Front. Public Health https:// doi.org/10.3389/fpubh.2020.00092 (2020).

100. Uyttendaele, M. et al. Microbial hazards in irrigation water: standards, norms, and testing to manage use of water in fresh produce primary production. Compr. Rev. Food Sci. Food Saf. 14, 336-356 (2015).

101. Reid, C. J., Blau, K., Jechalke, S., Smalla, K. \& Djordjevic, S. P. Whole genome sequencing of Escherichia coli from store-bought produce. Front. Microbiol. 10, 3050 (2020)

102. Blau, K. et al. The transferable resistome of produce. mBio 9, e01300-18 (2018).

103. Zhu, Y.-G. et al. Soil biota, antimicrobial resistance and planetary health. Environ. Int. 131, 105059 (2019).

104. Pal, C., Bengtsson-Palme, J., Kristiansson, E. \& Larsson, D. G. J. The structure and diversity of human, animal and environmental resistomes. Microbiome 4, 54 (2016)

105. Kozajda, A., Jeżak, K. \& Kapsa, A. Airborne Staphylococcus aureus in different environments a review. Environ. Sci. Pollut. Res. 26, 34741-34753 (2019).

106. Ashbolt, N. J. et al. Human health risk assessment (HHRA) for environmental development and transfer of antibiotic resistance. Environ. Health Perspect. 121 993-1001 (2013).

107. Franz, E., Schijven, J., De Roda Husman, A. M. \& Blaak, H. Meta-regression analysis of commensal and pathogenic Escherichia coli survival in soil and water. Environ. Sci. Technol. 48, 6763-6771 (2014).

108. Lewis, K. Platforms for antibiotic discovery. Nat. Rev. Drug. Discov. 12, 371-387 (2013)

109. Linton, K. B., Richmond, M. H., Bevan, R. \& Gillespie, W. A. Antibiotic resistance and $\mathrm{R}$ factors in coliform bacilli isolated from hospital and domestic sewage. J. Med. Microbiol. 7, 91-103 (1974).

110. Huijbers, P., Joakim Larsson, D. G. \& Flach, C. F Surveillance of antibiotic resistant Escherichia coli in human populations through urban wastewater in ten European countries. Environ. Pollut. 261, 114200 (2020).

111. Hutinel, M. et al. Population-level surveillance of antibiotic resistance in Escherichia coli through sewage analysis. Euro Surveill. https://doi.org/ 10.2807/1560-7917.es.2019.24.37.1800497 (2019).

112. Aarestrup, F. M. \& Woolhouse, M. E. J. Using sewage for surveillance of antimicrobial resistance. Science 367, 630-632 (2020)

113. Kwak, Y. K. et al. Surveillance of antimicrobial resistance among Escherichia coli in wastewater in Stockholm during 1 year: does it reflect the resistance trends in the society? Int. J. Antimicrob. Agents 45 , 25-32 (2015).

114. Parnanen, K. M. M. et al. Antibiotic resistance in European wastewater treatment plants mirrors the pattern of clinical antibiotic resistance prevalence. Sci. Adv. 5, eaau9124 (2019).

115. Hendriksen, R. S. et al. Global monitoring of antimicrobial resistance based on metagenomics analyses of urban sewage. Nat. Commun. 10 1124 (2019).

This is the most comprehensive survey of ARGs in sewage across the world to date, showing distinct differences between regions.

116. Huijbers, P. M. C., Flach, C. F. \& Larsson, D. G. J. A conceptual framework for the environmental surveillance of antibiotics and antibiotic resistance. Environ. Int. 130, 104880 (2019).

117. Böhm, M.-E., Razavi, M., Marathe, N. P., Flach, C.-F. \& Larsson, D. G. J. Discovery of a novel integron-borne aminoglycoside resistance gene present in clinical pathogens by screening environmental bacterial communities. Microbiome https://doi.org/10.1186/ s40168-020-00814-z (2020).

Using a functional assay targeting mobile genes, this study explores environment communities and finds a completely novel resistance gene that had escaped discovery in clinics despite its presence in pathogens on different continents.

118. Flach, C.-F., Hutinel, M., Razavi, M., Åhrén, C. \& Larsson, D. G. J. Monitoring of hospital sewage shows both promise and limitations as an early-warning system for carbapenemase-producing Enterobacterales in a low-prevalence setting. Water Res. 200, 117261 (2021).

119. Karkman, A. Berglund, F., Flach, C.-F. Kristiansson, E. $\&$ Larsson, D. G. J. Predicting clinical resistance prevalence using sewage metagenomic data. Commun. Biol. https://doi.org/10.1038/s42003020-01439-6 (2020).

120. European Centre for Disease Prevention and Control. Surveillance of antimicrobial resistance in Europe 2017 (Stockholm, Sweden, 2018).

121. Hovi, T. et al. Role of environmental poliovirus surveillance in global polio eradication and beyond Epidemiol. Infect. 140, 1-13 (2012).

122. Agrawal, S., Orschler, L. \& Lackner, S. Long-term monitoring of SARS-CoV-2 RNA in wastewater of the Frankfurt metropolitan area in southern Germany. Sci. Rep. https://doi.org/10.1038/s41598-021-84914-2 (2021).

123. Medema, G., Heijnen, L., Elsinga, G., Italiaander, R. $\&$ Brouwer, A. Presence of SARS-coronavirus-2 RNA in sewage and correlation with reported COVID-19 prevalence in the early stage of the epidemic in the Netherlands. Environ. Sci. Technol. Lett. 7, 511-516 (2020).

124. Lundstrom, S. V. et al. Minimal selective concentrations of tetracycline in complex aquatic bacterial biofilms. Sci. Total Environ. 553, 587-595 (2016).

125. McCann, C. M. et al. Understanding drivers of antibiotic resistance genes in High Arctic soil ecosystems. Environ. Int. 125, 497-504 (2019).

126. Pruden, A., Arabi, M. \& Storteboom, H. N. Correlation between upstream human activities and riverine antibiotic resistance genes. Environ. Sci. Technol. 46 11541-11549 (2012).

127. Zhu, Y.-G. et al. Continental-scale pollution of estuaries with antibiotic resistance genes. Nat. Microbiol. 2, 16270 (2017).

128. Zhu, Y.-G. et al. Diverse and abundant antibiotic resistance genes in Chinese swine farms. Proc. Nat Acad. Sci. USA 110, 3435-3440 (2013).

129. Knapp, C. W., Dolfing, J., Ehlert, P. A. I. \& Graham, D. W. Evidence of increasing antibiotic resistance gene abundances in archived soils since 1940. Environ. Sci. Technol. 44, 580-587 (2010).

130. Nesme, J. \& Simonet, P. The soil resistome: a critical review on antibiotic resistance origins, ecology and dissemination potential in telluric bacteria. Environ. Microbiol. 17, 913-930 (2015).

131. Finley, R. L. et al. The scourge of antibiotic resistance: the important role of the environment. Clin. Infect. Dis 57, 704-710 (2013)

132. Sjölund, M. et al. Dissemination of multidrug-resistant bacteria into the Arctic. Emerg. Infect. Dis. 14, 70-72 (2008).

133. Zhu, G. et al. Air pollution could drive global dissemination of antibiotic resistance genes. ISME J. https://doi.org/10.1038/s41396-020-00780-2 (2020).

134. Nichols, D. et al. Use of Ichip for high-throughput in situ cultivation of "Uncultivable" microbial species. Appl. Environ. Microbiol. 76, 2445-2450 (2010).

135. Ashton, P. M. et al. MinlON nanopore sequencing identifies the position and structure of a bacteria antibiotic resistance island. Nat. Biotechnol. 33 296-300 (2015)

136. Spencer, S. J. et al. Massively parallel sequencing of single cells by epicPCR links functional genes with phylogenetic markers. ISME J. 10, 427-436 (2016). 
137. Rice, E. W., Wang, P., Smith, A. L. \& Stadler, L. B. Determining hosts of antibiotic resistance genes: a review of methodological advances. Environ. Sci. Technol. Lett. 7, 282-291 (2020)

138. Sivalingam, P., Poté, J. \& Prabakar, K. Extracellular DNA (eDNA): neglected and potential sources of antibiotic resistant genes (ARGs) in the aquatic environments. Pathogens 9, 874 (2020).

139. Bengtsson-Palme, J., Larsson, D. G. J. \& Kristiansson, E. Using metagenomics to investigate human and environmental resistomes. J. Antimicrob. Chemother 72, 2690-2703 (2017)

140. Karkman, A. et al. High-throughput quantification of antibiotic resistance genes from an urban wastewater treatment plant. FEMS Microbiol. Ecol. 92, https://doi.org/10.1093/femsec/fiw014 (2016).

141. Gillings, M. R. et al. Using the class integron-integrase gene as a proxy for anthropogenic pollution. ISME J. 9, 1269-1279 (2015).

142. Gaze, W. H., Abdouslam, N., Hawkey, P. M. \& Wellington, E. M. H. Incidence of Class 1 integrons in a quaternary ammonium compound-polluted environment. Antimicrob. Agents Chemother. 49, 1802-1807 (2005)

143. Sommer, M. O. A., Munck, C., Toft-Kehler, R. V. \& Andersson, D. I. Prediction of antibiotic resistance: time for a new preclinical paradigm? Nat. Rev. Microbiol. 15, 689-696 (2017). This article highlights the needs to consider the environmental gene reservoir and other factors influencing resistance evolution in the development process for new antibiotics.

144. Pehrsson, E. C., Forsberg, K. J., Gibson, M. K. Ahmadi, S. \& Dantas, G. Novel resistance functions uncovered using functional metagenomic investigations of resistance reservoirs. Front. Microbiol. https://doi.org/ 10.3389/fmicb.2013.00145 (2013).

145. Kim, C., Ryu, H.-D., Chung, E. G., Kim, Y. \& Lee, J.-K. A review of analytical procedures for the simultaneous determination of medically important veterinary antibiotics in environmental water: sample preparation, liquid chromatography, and mass spectrometry. J. Environ. Manag. 217, 629-645 spectrometr.
(2018).

146. Fahrenfeld, N. \& Bisceglia, K. J. Emerging investigators series: sewer surveillance for monitoring antibiotic use and prevalence of antibiotic resistance: urban sewer epidemiology. Environ. Sci. Water Res. Technol. 2, 788-799 (2016).

147. Anliker, S. et al. Assessing emissions from pharmaceutical manufacturing based on temporal high-resolution mass spectrometry data. Environ. Sci. Technol. 54, 4110-4120 (2020).

This recent study elegantly uses the erratic emission profiles of drugs from manufacturing plants to attribute a large portion of the pharmaceutical residues found in a Swiss river to industrial emissions, further showing that curbing such pollution is an ongoing, worldwide challenge.

148. Klümper, U. et al. Selection for antimicrobial resistance is reduced when embedded in a natural microbial community. ISME J. 13, 2927-2937 (2019).
149. Kraupner, N. et al. Selective concentrations for trimethoprim resistance in aquatic environments. Environ. Int. 144, 106083 (2020).

150. Murray, A. K. et al. Novel insights into selection for antibiotic resistance in complex microbial communities. mBio https://doi.org/10.1128/mbio.00969-18 (2018).

151. Government of India. Environment (Protection) Amendment Rules, 2020 - Inviting comments/ suggestions on Environmental Standards for Bulk Drug and Formulation (Pharmaceutical) Industry. http://moef govin/g-s-r-44-e-date-23-01-2020environment-protection-amendment-rules2020-inviting-commentssuggestions-onenvironmental-standards-for-bulk-drug-andformulation-pharmaceutical-indu/ (2020).

152. Tell, J. et al. Science-based targets for antibiotics in receiving waters from pharmaceutical manufacturing operations. Integr. Environ. Assess. Manag. 15, 312-319 (2019)

153. Greenfield, B. K. et al. Modeling the emergence of antibiotic resistance in the environment: an analytical solution for the minimum selection concentration. Antimicrob. Agents Chemother. https://doi.org/ 10.1128/aac.01686-17 (2018).

154. Murray, A. K. et al. The 'Selection end points in Communities of bacTeria' (SELECT) method: a novel experimental assay to facilitate risk assessment of selection for antimicrobial resistance in the environment. Environ. Health Perspect. 128 107007 (2020).

155. Andersson, D. I. \& Hughes, D. Antibiotic resistance and its cost: is it possible to reverse resistance? Nat. Rev. Microbiol. 8, 260-271 (2010)

156. Stanton, I. C., Murray, A. K., Zhang, L., Snape, J. $\&$ Gaze, W. H. Evolution of antibiotic resistance at low antibiotic concentrations including selection below the minimal selective concentration. Commun. Biol. https://doi.org/10.1038/s42003-020-01176-w (2020).

157. Nijsingh, N., Munthe, C. \& Larsson, D. G. J. Managing pollution from antibiotics manufacturing: charting actors, incentives and disincentives. Environ. Health 18, 95 (2019).

158. Sundin, G. W. \& Wang, N. Antibiotic resistance in plant-pathogenic bacteria. Annu. Rev. Phytopathol. 56, 161-180 (2018)

159. Government of Sweden. Uppdrag angående försöksverksamhet för en miljöpremie i läkemedelsförmånssystemet, https://www. regeringen.se/499677/contentassets/ 36dcec65be904fd58e5e6b01c2f99709/ uppdrag-angaende-forsoksverksamhet-for-enmiljopremie-i-lakemedelsformanssystemet-tlv.pdf (2021).

160. Norwegian Hospital Procurement Trust. New environmental criteria for the procurement of pharmaceuticals, https://sykehusinnkjop.no/nyheter/ new-environmental-criteria-for-the-procurementof-pharmaceuticals (2019).

161. Swedish Procurement Agency. Pharmaceuticals, https://www.upphandlingsmyndigheten.se/kriterier/ sjukvard-och-omsorg/lakemedel/ (2021).
162. G7. G7 Health Ministers' Declaration, Oxford, 4 June 2021, https://assets. publishing.service.gov.uk/ government/uploads/system/uploads/attachment data/file/992268/G7-health_ministers-communiqueoxford-4-june-2021_5.pdf (2021).

163. Årdal, C. et al. Supply chain transparency and the availability of essential medicines. Bull. World Health Organ. 99, 319-320 (2021).

164. Graham, D., Giesen, M. \& Bunce, J. Strategic approach for prioritising local and regional sanitation interventions for reducing global antibiotic resistance. Water 11, 27 (2018)

165. Margot, J. et al. Treatment of micropollutants in municipal wastewater: ozone or powdered activated carbon? Sci. Total. Environ. 461-462, 480-498 (2013).

166. Larsson, D. G. J. et al. Critical knowledge gaps and research needs related to the environmental dimensions of antibiotic resistance. Environ. Int. 117, 132-138 (2018).

167. Laxminarayan, R. et al. The Lancet Infectious Diseases Commission on antimicrobial resistance: 6 years later. Lancet Infect. Dis. 20, e51-e60 (2020).

168. Ahammad, Z. S., Sreekrishnan, T. R., Hands, C. L., Knapp, C. W. \& Graham, D. W. Increased waterborne blaNDM-1 resistance gene abundances associated with seasonal human pilgrimages to the upper Ganges River. Environ. Sci. Technol. 48, 3014-3020 (2014).

169. Kookana, R. S. et al. Potential ecological footprints of active pharmaceutical ingredients: an examination of risk factors in low-, middle- and high-income countries. Philos. Trans. R. Soc. B Biol. Sci. 369, 20130586 (2014).

\section{Acknowledgements}

Work in the authors' laboratories was funded by the Swedish research councils VR (2018-02835 and 2018-05771) and FORMAS (2108-00787) and the Region Västra Götaland under the ALF agreement (grant number ALFGBG-717901) to D.G.J.L. as well as FORMAS (2018-00833) to C.-F.F.

\section{Author contributions}

D.G.J.L. and C.-F.F. researched data for the article, contributed to the discussion of the content, and reviewed and edited the manuscript before submission. D.G.J.L. wrote the article.

\section{Competing interests}

The authors declare no competing interests.

Peer review information

Nature Reviews Microbiology thanks J. Martínez, K. Smalla and the other, anonymous, reviewer(s) for their contribution to the peer review of this work.

Publisher's note

Springer Nature remains neutral with regard to jurisdictional claims in published maps and institutional affiliations.

(C) Springer Nature Limited 2021 